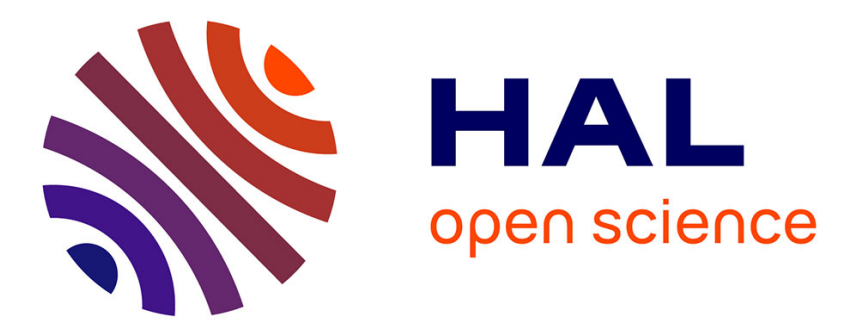

\title{
Role of the tachykinin NK receptor in mediating contraction to 5-hydroxytryptamine and antigen in the mouse trachea
}

Katelijne O. de Swert, Romain A. Lefebvre, Romain A. Pauwels, Guy F. Joos

\section{- To cite this version:}

Katelijne O. de Swert, Romain A. Lefebvre, Romain A. Pauwels, Guy F. Joos. Role of the tachykinin NK receptor in mediating contraction to 5-hydroxytryptamine and antigen in the mouse trachea. Pulmonary Pharmacology \& Therapeutics, 2007, 20 (5), pp.588. 10.1016/j.pupt.2006.06.005 . hal00499136

\section{HAL Id: hal-00499136 https://hal.science/hal-00499136}

Submitted on 9 Jul 2010

HAL is a multi-disciplinary open access archive for the deposit and dissemination of scientific research documents, whether they are published or not. The documents may come from teaching and research institutions in France or abroad, or from public or private research centers.
L'archive ouverte pluridisciplinaire HAL, est destinée au dépôt et à la diffusion de documents scientifiques de niveau recherche, publiés ou non, émanant des établissements d'enseignement et de recherche français ou étrangers, des laboratoires publics ou privés. 


\section{Author's Accepted Manuscript}

Role of the tachykinin $\mathrm{NK}_{1}$ receptor in mediating contraction to 5-hydroxytryptamine and antigen in the mouse trachea

Katelijne O. De Swert, Romain A. Lefebvre, Romain A. Pauwels, Guy F. Joos

PII: $\quad$ S1094-5539(06)00070-8

DOI: $\quad$ doi:10.1016/j.pupt.2006.06.005

Reference: $\quad$ YPUPT 693

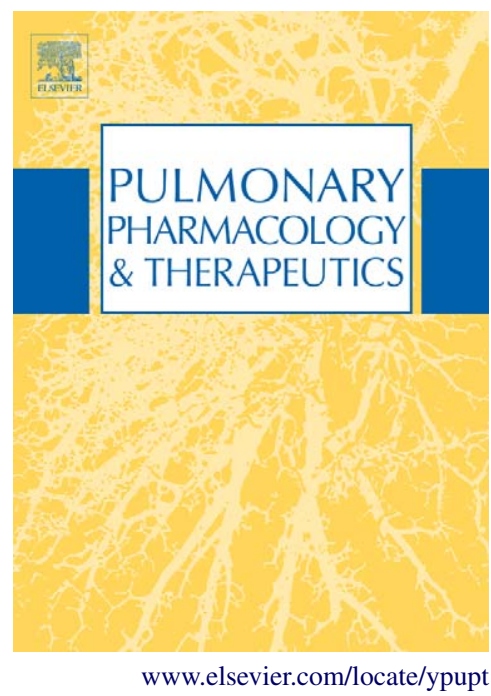

To appear in: Pulmonary Pharmacology \& Therapeutics

Received date: 27 July 2005

Revised date: 5 February 2006

Accepted date: 30 June 2006

Cite this article as: Katelijne O. De Swert, Romain A. Lefebvre, Romain A. Pauwels and Guy F. Joos, Role of the tachykinin $\mathrm{NK}_{1}$ receptor in mediating contraction to 5hydroxytryptamine and antigen in the mouse trachea, Pulmonary Pharmacology \& Therapeutics, doi:10.1016/j.pupt.2006.06.005

This is a PDF file of an unedited manuscript that has been accepted for publication. As a service to our customers we are providing this early version of the manuscript. The manuscript will undergo copyediting, typesetting, and review of the resulting galley proof before it is published in its final citable form. Please note that during the production process errors may be discovered which could affect the content, and all legal disclaimers that apply to the journal pertain. 
Regular paper

$26^{\text {th }}$ july 2005

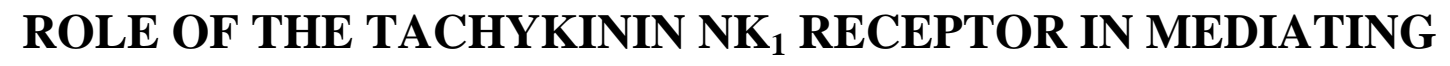

CONTRACTION TO 5-HYDROXYTRYPTAMINE AND ANTIGEN IN

THE MOUSE TRACHEA

\author{
Katelijne O. De Swert ${ }^{1}$; Romain A. Lefebvre ${ }^{2}$; Romain A. Pauwels ${ }^{1}$ \\ and Guy F. Joos ${ }^{1}$ \\ ${ }^{1}$ Dept. Respiratory Diseases, Ghent University Hospital \\ ${ }^{2}$ Heymans Institute of Pharmacology, Faculty of Medicine, Ghent University, \\ De Pintelaan 185, 9000 Ghent, Belgium
}

Correspondence and reprint requests:

Katelijne De Swert

Tel : +32 92402359

Fax : +32 92402341

E-mail : Katelijne.Deswert@UGent.be

Running title: The tachykinin $\mathrm{NK}_{1}$ receptor modulates 5-HT-induced contractions

Number of text pages: 16

Number of figures: 5

Number of tables: 1 


\section{Abstract}

Neuroimmune interactions are important in airway diseases such as asthma. We evaluated the role of the tachykinin $\mathrm{NK}_{1}$ receptor in the contractile response of isolated trachea from tachykinin $\mathrm{NK}_{1}$ receptor wild-type and knockout mice, to the antigen ovalbumin and the contractile agonist serotonin (5-hydroxytryptamine). 1\% ovalbumin induced contractions of tracheas obtained from ovalbumin-immunized and exposed mice. The tracheas from wild-type animals showed larger contractions compared to the knockout mice. Tracheas from sensitised and ovalbumin-exposed animals released 5-hydroxytyptamine upon addition of ovalbumin. Higher levels of 5-hydroxytryptamine were released from tracheas of wild-type animals. Tracheas of non-sensitised animals did not release 5-hydroxytryptamine upon ovalbumin challenge. Responses to ovalbumin were abrogated by methysergide, a broad 5hydroxytryptamine receptor antagonist. Exogenous 5-hydroxytryptamine contracted tracheas but wild-type tracheas responded significantly more. Atropine and tetrodotoxin reduced 5hydroxytryptamine-induced contractions of the wild-type tracheas, while they did not affect 5-hydroxytryptamine-induced contractions of knockout tracheas. 5-hydroxytryptamine induced contractions from atropine- or tetrodotoxin-treated wild-type tracheas did not differ significantly from the contractions of the knockout tracheas. Single tachykinin $\mathrm{NK}_{1}$ receptor antagonists SR140333 and RP67580 had no effect on 5-hydroxytryptamine-induced contractions. In conclusion, the 5-hydroxytryptamine-induced tracheal contraction includes a cholinergic mechanism that requires the presence of the tachykinin $\mathrm{NK}_{1}$ receptor.

\section{$\underline{\text { Keywords }}$}

Substance P, knockout mice, airway contraction, tachykinins, 5-hydroxytryptamine, asthma 


\section{Introduction}

Substance $\mathrm{P}$ is a member of the tachykinin peptide family and is localized in the sensory afferent nerves and inflammatory cells of the airways. Structural elements, like epithelium may be an additional source. Tachykinins may be released by a variety of stimuli (e.g. cigarette smoke, ozone) and they generate a range of effects that are potentially relevant in the pathogenesis of asthma [1]. Their effects are mediated through specific receptors, the tachykinin $\mathrm{NK}_{1}, \mathrm{NK}_{2}$ and $\mathrm{NK}_{3}$ receptors. In the airways, tachykinin $\mathrm{NK}_{1}$ receptors, the high affinity receptors for substance $\mathrm{P}$, are mainly involved in proinflammatory effects while $\mathrm{NK}_{2}$ receptors, preferential receptors for neurokinin A, are considered to be important in smooth muscle contraction.

Airways of atopic asthmatics respond to inhalation of allergen with an immediate bronchoconstriction, the early asthmatic response. This bronchoconstriction is induced by IgE-mediated release of mast cell mediators like prostaglandins, cysteinyl-leukotrienes and others [2]. The importance of mast cells in the antigen-induced bronchoconstriction has also been demonstrated in various animal models, including mice [3;4]. In the airways, a close anatomical relationship exists between mast cell and neurons and these neurons have been shown to be immunoreactive for substance P (reviewed in [5]). A direct interaction between these two cell types has been suggested [6]. Functional evidence exists for the presence of tachykinin $\mathrm{NK}_{1}$ receptors on mast cells [7-9]. Substance $\mathrm{P}$ is able to induce degranulation of human and rat mast cells, which can lead to bronchoconstriction [10;11]. Low concentrations of substance P can prime or sensitise mast cells to other stimuli [12]. The interaction may be bi-directional. In vitro, neurites are activated in response to mast cell activation [6] and many studies have shown that mast cell derived products like histamine and 5-HT modulate sensory neurotransmission [13-15]. Therefore, a role for the tachykinin $\mathrm{NK}_{1}$ receptor in mast cell mediated bronchoconstriction could be suspected. However, a clear involvement has not been demonstrated yet.

Exogenous 5-HT is also known to cause bronchoconstriction in rats and mice. However, the observed bronchoconstriction in rodents is strain dependent [16]. 5-HT can have a direct contractile effect by the interaction with 5- $\mathrm{HT}_{2}$ receptors on airway smooth muscle and an indirect effect by stimulation of cholinergic nerves and the subsequent release of acetylcholine [17-19]. Recently, it was shown in mice that 5-HT was able to release acetylcholine from the epithelium as well [20]. It is important to know by which exact mechanism 5-HT contract the airways as rodents are often used in disease models for asthma. As 5-HT modulates sensory neurotransmission, the tachykinin $\mathrm{NK}_{1}$ receptor might be 
involved in the response to exogenous 5-HT too. Furthermore, in the central nervous system it was shown that the absence of the tachykinin $\mathrm{NK}_{1}$ receptor resulted in the functional desensitisation / downregulation of 5-HT receptors [21].

The aim of our study was to examine a possible involvement of the tachykinin $\mathrm{NK}_{1}$ receptor in the tracheal contractile response to antigen and to exogenous 5-HT. Therefore, we evaluated 5-HT- and antigen-induced tracheal smooth muscle contraction from mice lacking the tachykinin $\mathrm{NK}_{1}$ receptor and compared this response to that of the wild type counterparts. Our results demonstrate an involvement of the tachykinin $\mathrm{NK}_{1}$ receptor in 5-HT-induced smooth muscle contraction and in antigen-induced smooth muscle contraction by interaction with cholinergic mechanisms.

\section{Materials and methods}

\subsection{Mice:}

Tachykinin $\mathrm{NK}_{1}$ receptor wild type (WT) and knockout (KO) mice were derived as described from the mating of heterozygous tachykinin $\mathrm{NK}_{1}$ receptor $^{+/-}$mice [22]. The targeting construct was derived from a mouse 129/sv strain genomic library and targeted clones were injected into $\mathrm{C} 57 \mathrm{Bl} / 6$ blastocysts. Chimaeric males were mated with $\mathrm{C} 57 \mathrm{Bl} / 6$ females. The mice were bred from successive generations of sibling $\mathrm{KO}$ and WT mice and can be thought of as representing a recombinant inbred strain. The respective tachykinin $\mathrm{NK}_{1}$ receptor $\mathrm{KO}$ and WT breeding pairs were provided by the lab of S. Hunt (Cambridge, UK). The animals were bred locally and maintained under germ free conditions in a conventional animal house in the animal research facilities of the Department of Respiratory Diseases of the University Hospital, Ghent and received food and water ad libitum. The used protocols comply with the European Community guidelines and were approved by the local ethics committee.

\subsection{Immunization and exposure of mice:}

On day 0, test mice (female, 8-10 weeks) were actively immunized with ovalbumin (Grade III; Sigma chemical Co.) by intraperitoneal injection of $10 \mu \mathrm{g}$ ovalbumin, adsorbed to $1 \mathrm{mg}$ $\mathrm{Al}(\mathrm{OH})_{3}$. Control mice received only adjuvant. From day 14 to 21, the mice were exposed daily to phosphate buffered saline (PBS) or ovalbumin aerosols (1\%) for $30 \mathrm{~min}$ in a Plexiglas exposure chamber $(30 \times 20 \times 15 \mathrm{~cm})$. The aerosol was generated by an ultrasonic nebulizer (Ultraschallvernebler Sirius Nova, Heyer Medizintechnologie, Bad Ems, Germany). According to the specifications of the manufacturer, the output of the nebulizer was $3 \mathrm{ml} / \mathrm{min}$ and the mean particle size of the aerosol was $3.2 \mu \mathrm{m}$. 24 hours after the last exposure, mice were sacrificed and tracheas were excised. 


\subsection{General procedure:}

All experiments were performed with female mice of 8 to 10 weeks of age. The mice were killed by an intraperitoneal injection of pentobarbital (Nembutal ${ }^{\circledR}, 100 \mathrm{mg} / \mathrm{kg}$ ). The trachea was gently excised and the adhering connective tissue was carefully dissected and removed under microscopy guidance. The whole tracheas were mounted in a $2 \mathrm{ml}$ organ bath containing Krebs solution (composition in $\mathrm{mM}$ : $\mathrm{NaCl} 118, \mathrm{KCl}$ 4.6, $\mathrm{CaCl}_{2}$ 2.5, $\mathrm{MgSO}_{4} 1.15$, $\mathrm{NaHCO}_{3} 24.9, \mathrm{KH}_{2} \mathrm{PO}_{4} 1.15$ and glucose 5.5), which was maintained at $37^{\circ} \mathrm{C}$ and bubbled with carbogen $\left(5 \% \mathrm{CO}_{2}, 95 \% \mathrm{O}_{2}\right)$. The optimal resting tension on the trachea of this mouse strain was $0.7 \mathrm{~g}$, as determined by length-tension experiments. The tracheas were allowed to stabilize for 15 minutes at this resting tension. After this stabilization period, increasing concentrations of carbachol were added to the organ bath in a non-cumulative way $(0.33,1.00$ and $3.3 \mu \mathrm{M})$. The contact time for each concentration was 15 minutes. Between the administrations, an interval of 10 min was inserted, while the bathing medium was changed. This was followed by a resting period of 30 minutes while the bathing medium being changed every 10 minutes. The contractions were measured isometrically with Grass FT03 transducers (Grass Instruments Co., Quincy, MA, USA) and recorded on a Graphtec Linearecorder type WR3701 (Graphtech corp. Tokyo, Japan). Contractions were expressed as percent of the contraction that was observed using a maximal concentration of carbachol, as tracheas of both tachykinin $\mathrm{NK}_{1}$ receptor $\mathrm{WT}$ as $\mathrm{KO}$ animals were shown previously to respond similarly to carbachol [23].

\subsection{Effect of ovalbumin on the tracheal ring tension:}

The tracheas were exposed to ovalbumin by adding $1 \%$ ovalbumin in Krebs solution into the organ bath. The effect of methysergide $\left(10^{-7} \mathrm{M}\right)$ was evaluated by adding this 5-HT antagonist to the bathing medium 30 minutes before the addition of ovalbumin.

\subsection{In vitro release of $5-\mathrm{HT}$ :}

At the moment of maximal contraction induced by ovalbumin, $200 \mu$ l was taken from the organ bath to measure 5-HT. 5-HT was measured by the use of an enzyme-immunoassay. The assay is based on the competition of acylated 5-HT and the acylated enzyme-conjugate 5-HTacetylcholinesterase for an antibody against acylserotonin (Immunotech, Marseilles, France). The sensitivity of this assay is $0.5 \mathrm{nM}$.

\subsection{Effects of histamine and 5-HT on the tracheal ring tension:}

Tracheas were excised from control, non-immunized, non-exposed mice. Increasing concentrations of histamine $\left(10^{-8}\right.$ to $\left.10^{-4} \mathrm{M}\right)$ were added to the organ bath in a non-cumulative way (in steps of $0.5 \log$ [concentration]), whereby the contact time for each concentration was 
at least 4 minutes. Concentration-response curves to 5-HT were constructed after the stabilization period with carbachol and the subsequent resting period, by adding increasing concentrations to the organ bath in a cumulative way $\left(10^{-8} \mathrm{M}\right.$ to $\left.10^{-4} \mathrm{M}\right)$. The contact time for each concentration was at least $4 \mathrm{~min}$. Due to the occurrence of tachyphylaxis, only one concentration-response curve of 5-HT could be obtained. The effect of methysergide $\left(10^{-7} \mathrm{M}\right)$ was evaluated by adding the 5-HT antagonist to the bathing medium 30 minutes before the construction of the concentration-response curve to 5-HT.

2.7. Modulation of the 5-HT-induced contractions by atropine, tetrodotoxin, SR140333 and RP67580:

A concentration-response curve to 5-HT was performed as previously described in the presence and absence of atropine $\left(10^{-6} \mathrm{M}\right)$, tetrodotoxin (TTX) $\left(10^{-6} \mathrm{M}\right)$, SR140333 $\left(10^{-7} \mathrm{M}\right)$ and RP67580 $\left(10^{-7} \mathrm{M}\right)$. The substances were added to the bathing medium, starting from the resting period and during the construction of the concentration-response curve. Nonimmunized, non-exposed animals were used.

\subsection{Materials:}

Most drugs and chemicals were purchased from Sigma Chemical Co. (Poole, UK). Nembutal was from Sanofi (Libourne, France). PBS was from Gibco (Invitrogen, Merelbeke, Belgium). The tachykinin $\mathrm{NK}_{1}$ receptor antagonist SR140333 was a gift from X. Emonds-Alt (Sanofi Recherche, Montpellier, France). RP67580 was obtained from Tocris Cookson Ltd. (Avonmouth, UK). Stock solutions of these antagonists were prepared with ethanol p.a. (Merck, Brussels, Belgium) and further diluted in Krebs solution as appropriate. TTX was dissolved in ultrapure water. Other stock solutions were prepared with Krebs solution. All dilutions of drugs were prepared on the day of the experiments.

\subsection{Statistical analysis:}

The results are reported as mean \pm standard error of the mean (SEM). Concentration-response curves in the absence and presence of antagonists, TTX and atropine (multiple comparisons) were analysed with the General Linear Model Univariate procedure, providing regression analysis and analysis of variance for one dependent variable by two factors (the groups and the concentrations). Post-hoc analysis (Scheffé) for groups was performed when significance was reached. The differences in ovalbumin-induced contractions between groups were evaluated using Kruskall Wallis $\mathrm{H}$ test and Mann Whitney $\mathrm{U}$ for comparing individual groups. Significance levels were adapted with Bonferroni's conservative correction for repetitive measurements. Differences were regarded as significant when $\mathrm{p}<0.05$. The 
statistical analyses were accomplished with SPSS for Windows 11.0 software (SPSS Inc., Chicago, Illinois).

\section{Results}

\subsection{Contractile response of tracheas to ovalbumin}

Addition of $1 \%$ ovalbumin into the organ bath induced a marked contraction in both the immunized and exposed tachykinin $\mathrm{NK}_{1}$ receptor $\mathrm{WT}$ and $\mathrm{KO}$ animals. This reaction was significantly larger in the WT animals $(n=6)(p<0.05)$ (table 1$)$. Tracheas from shamimmunized and PBS exposed mice did not respond to the antigen. Ovalbumin induced the release of 5-HT in the organ bath but no differences were observed between the tracheas from tachykinin $\mathrm{NK}_{1}$ receptor $\mathrm{WT}$ and $\mathrm{KO}$ animals (WT: $2.3 \mathrm{nM} \pm 0.9$; KO: $4.3 \mathrm{nM} \pm 1.5, \mathrm{p}>0.05$; $\mathrm{n}=4$; non-sensitised animals: below detection limit). Pretreatment with the 5-HT antagonist methysergide abolished the response to ovalbumin completely in both WT and KO animals ( $p<0.05$ vs. solvent treated counterparts, $n=4$ ) (table 1 ).

\subsection{Contractile response of tracheas to 5-HT and histamine}

The tracheas of the non-immunized, non-exposed tachykinin $\mathrm{NK}_{1}$ receptor $\mathrm{WT}$ and the $\mathrm{KO}$ animals did not contract after histamine addition ( $n=5$, results not shown). 5-HT induced contractions in a concentration-dependent way. A bell-shaped concentration-response curve was observed (figure 1). The tracheas of the WT mice responded significantly more to the increasing concentrations of $5-\mathrm{HT}$ in comparison with the tracheas of the tachykinin $\mathrm{NK}_{1}$ receptor KO mice $(\mathrm{n}=8)(\mathrm{p}<0.05)$ (figure 1$)$. All responses to 5 -HT were abolished in the presence of methysergide (results not shown).

\subsection{Modulation of the 5-HT-induced contractions by atropine}

Pre-treatment of the tracheas of non-immunized, non-exposed mice with $10^{-6} \mathrm{M}$ atropine reduced the 5-HT-induced contractions in the tachykinin $\mathrm{NK}_{1}$ receptor WT $(\mathrm{p}<0.05$ vs. solvent-treated WT tracheas) (figure 2) $(n=5)$. At a concentration of $10^{-6} \mathrm{M}$, atropine had no effect on the 5-HT-induced contractions of the tracheas from KO mice $(n=5) \quad(p>0.05$ atropine- vs. solvent-treated KO tracheas) (figure 2). 5-HT-induced contractions of atropinetreated WT tracheas did not differ significantly from the tracheal contractions of the KO animals ( $\mathrm{p}>0.05$ vs. solvent- and atropine-treated KO tracheas) (figure 2).

\subsection{Modulation of the 5-HT-induced contractions by TTX}

To evaluate possible neural effects, the response to 5-HT was studied in the presence of the neurotoxin TTX $\left(10^{-6} \mathrm{M}\right)$. Tracheas obtained from non-immunized, non-exposed tachykinin $\mathrm{NK}_{1}$ receptor WT mice responded significantly less to 5-HT in the presence of TTX $(\mathrm{p}<0.05$ 
vs. solvent treated tracheas, $n=5$ ). Concentration-response curves of 5-HT on tracheas from KO animals were not influenced by TTX ( $>0.05$ TTX- vs. solvent-treated KO tracheas). The observed responses of the WT tracheas were not significantly different from responses obtained in tracheas from tachykinin $\mathrm{NK}_{1}$ receptor $\mathrm{KO}$ mice ( $>0.05$ vs. solvent- and TTXtreated KO tracheas) (figure 3).

3.5. Modulation of the 5-HT-induced contractions by the tachykinin $\mathrm{NK}_{1}$ receptor antagonists

\section{$\underline{\text { SR140333 and RP67580 }}$}

Pre-treatment of the WT tracheas with the tachykinin $\mathrm{NK}_{1}$ receptor antagonists RP67580 $\left(10^{-7}\right.$ $\mathrm{M})$ and SR140333 $\left(10^{-7} \mathrm{M}\right)$ did not influence the 5-HT-induced contractions. No significant differences were observed between concentration-response curves from solvent-treated WT tracheas and antagonist-treated WT tracheas ( $\mathrm{n}=6$, figure 4A and B respectively).

\section{Discussion}

Tracheal tissue from mice sensitised and exposed to ovalbumin showed an immediate contractile response to the antigen in vitro. However, tracheas from mice lacking the tachykinin $\mathrm{NK}_{1}$ receptor responded significantly less compared to their WT counterparts. Exogenous 5-HT induced also contraction of the tracheal smooth muscle of non-immunized, non-exposed animals. Again, the tracheas from the tachykinin $\mathrm{NK}_{1}$ receptor $\mathrm{KO}$ animals responded significantly less. Responses to antigen and 5-HT were abolished in the presence of methysergide. Atropine and TTX did not influence responses to 5-HT in tachykinin $\mathrm{NK}_{1}$ receptor KO mice but lowered 5-HT-induced contractions in WT tracheas. No effect of tachykinin $\mathrm{NK}_{1}$ receptor antagonists SR140333 and RP67580 vs. 5-HT could be demonstrated in WT tracheas.

The observed contractile response to antigen is due to activation of mast cells via antigen cross-linking of IgE antibodies bound on the high affinity IgE receptor FceRI [24]. It is important to note that no differences in serum ovalbumin-specific IgE levels between the tachykinin $\mathrm{NK}_{1}$ receptor WT and KO mice can be detected [25]. Upon activation, mast cells degranulate, thereby releasing a variety of mediators like histamine and 5-HT, which in their turn induce contraction $[4 ; 26]$. Indeed, after stimulation with the antigen, the presence of 5HT in the organ bath was demonstrated. Furthermore, methysergide, a 5-HT1 and 5-HT2 combined receptor antagonist, abolished the contractile response to ovalbumin. These findings are in accordance with the findings of Nagase and colleagues. They reported a specific role for 5-HT2 receptors in antigen-induced airway smooth muscle constriction [27]. Also Eum and colleagues demonstrated the importance of 5-HT in antigen-induced 
contractions [19]. As equal amounts of 5-HT were released from tracheas of tachykinin $\mathrm{NK}_{1}$ receptor WT and $\mathrm{KO}$ animals, it is suggested that the tachykinin $\mathrm{NK}_{1}$ receptor was not involved in the triggering of the mast cell by the antigen and the subsequent release of its mediators. Although histamine can be released from murine mast cells, exogenous histamine did not elicit contractions in this model. This is in agreement with previous findings obtained in rat [28;29]. Exogenous 5-HT induced tracheal contractions but responses were smaller in tachykinin $\mathrm{NK}_{1}$ receptor $\mathrm{KO}$ animals. Responses to 5-HT were abolished by the presence of methysergide demonstrating a receptor-mediated event. The contractile effect of 5-HT has previously been demonstrated in rats [17] and in mice but this depended on the inbred strain of mice used [16;18]. Often, a cholinergic component was demonstrated. Furthermore, 5-HT has a facilitatory effect on cholinergic neurotransmission in human [30], mouse [18], rat [31] and guinea pig [32] airways. In our model, a cholinergic component is also demonstrated. Atropine reduced the contractile response to 5-HT in the tachykinin $\mathrm{NK}_{1}$ receptor WT tracheas, suggesting the 5-HT-induced release of acetylcholine. We hypothesized that the acetylcholine arose from cholinergic nerve endings. The neural character of this phenomenon was confirmed by the fact that TTX, a neurotoxin, also reduced the 5-HT-induced contractions of tracheas from the tachykinin $\mathrm{NK}_{1}$ receptor WT mice. However, neither atropine nor TTX influenced the 5-HT-induced tracheal contractions of tachykinin $\mathrm{NK}_{1}$ receptor KO mice. This suggests that the tachykinin $\mathrm{NK}_{1}$ receptor is pivotal for the 5-HTinduced release of acetylcholine. A different sensitivity of the tracheal smooth muscle to 5HT between the tachykinin $\mathrm{NK}_{1}$ receptor WT and KO mice is not very likely since there were no longer differences between the contractile responses of both groups to 5-HT in the presence of atropine or TTX. Furthermore, we previously showed that the tracheal smooth muscle preparation of the WT and KO mice respond similar to the cholinergic agonist carbachol [23]. A generalized artifact of cholinergic nerve activity seems unlikely too, since electrical field stimulation of the tracheas from $\mathrm{NK}_{1}$ receptor knockout animals still generated acetylcholine release and acetylcholine-mediated contraction although this release and contraction were diminished compared to the response in the WT counterparts [23].

The difference in the OA-induced contractions between the tachykinin $\mathrm{NK}_{1}$ receptor $\mathrm{WT}$ and KO animals seems larger than the observed difference between the concentration-response curves to 5-HT. It is important to notice that the response to OA was evaluated with a single concentration of the OA while the effects of exogenous 5-HT were evaluated with a concentration-response curve. This may lead to a misinterpretation of the results. However, it seems plausible that due to the close relationship between mast cells and nerves, the effect of 
the endogenously released 5-HT is more extensively directed towards the proximal cholinergic nerves while in the response to exogenous 5-HT, the muscular component becomes more important.

There are several possible explanations for the involvement of the tachykinin $\mathrm{NK}_{1}$ receptor in the 5-HT induced release of acetylcholine from cholinergic nerve endings. Functional evidence exists for the presence of 5-HT receptors on sensory nerve endings. Activation of these receptors with their ligand 5-HT may result in the release of tachykinins [33;34]. The released substance P may in its turn facilitate or permit the release of acetylcholine [23]. Such cascade has previously been suggested in guinea pig ileum [35]. However, we dismissed this hypothesis by the use of specific tachykinin $\mathrm{NK}_{1}$ receptor antagonists. SR140333, a specific $\mathrm{NK}_{1}$ receptor antagonist, did not influence the 5-HT induced contractions of tracheas from tachykinin $\mathrm{NK}_{1}$ receptor WT animals. The used concentration of SR140333 is sufficient to antagonize the tachykinin $\mathrm{NK}_{1}$ receptor sufficiently as was previously demonstrated in our model [23]. Higher concentrations of the tachykinin $\mathrm{NK}_{1}$ receptor antagonist were no longer specific as tracheas from tachykinin $\mathrm{NK}_{1}$ receptor $\mathrm{KO}$ animals were also influenced (results not shown). Furthermore, another specific tachykinin $\mathrm{NK}_{1}$ receptor antagonist RP67580 also failed to influence the 5-HT induced contractions of tracheas from the tachykinin $\mathrm{NK}_{1}$ receptor WT mice. Again, the used concentration should be sufficient as the $K_{i}$ value for this antagonist is $2.9 \mathrm{nM}$ for rat tachykinin $\mathrm{NK}_{1}$ receptors. These antagonist studies suggest that the tachykinin $\mathrm{NK}_{1}$ receptor is not involved in the immediate contractile response to 5-HT. Similar findings were reported in guinea pigs [32]. However, long-term blockade of the tachykinin $\mathrm{NK}_{1}$ receptor may induce developmental compensations that lead to the observed difference in the cholinergic aspect of the 5-HT induced tracheal contractions. In the central nervous system, the lack of the tachykinin $\mathrm{NK}_{1}$ receptor resulted in the functional desensitisation / downregulation of the presynaptic $5-\mathrm{HT}_{1 \mathrm{~A}}$ receptor [21;36]. Our results suggest a similar downregulation of 5-HT receptors on peripheral nerve endings in our mouse model.

To conclude, our data confirm previous findings that the immediate response to allergen in mouse trachea in vitro is mediated through the release of 5-HT from mast cells. The released 5-HT mediates contraction through activation of receptors on smooth muscle and through activation of presynaptic receptors on cholinergic nerve endings. We found that this cholinergic mechanism is impaired in mice lacking the tachykinin $\mathrm{NK}_{1}$ receptor, probably through downregulation of the peripheral presynaptic 5-HT receptors on cholinergic nerve endings (figure 5). It is tempting to speculate that long-term addition of tachykinin $\mathrm{NK}_{1}$ 
receptor antagonists may render cholinergic nerve endings less sensitive to mast cell mediators which may have important implications in mast cell related disorders such as asthma. 


\section{Acknowledgments}

The authors would like to thank Prof. Dr. S. Hunt (Cambridge, UK) for kindly providing the tachykinin $\mathrm{NK}_{1}$ receptor wild-type and knockout breeding pairs and Dr. X. Emonds-Alt (Sanofi Recherche, Montpellier, France) for providing the specific $\mathrm{NK}_{1}$ receptor antagonist, SR140333. They also gratefully acknowledge the skilful technical assistance of G. Van der Reysen. Special thanks to E. Castrique for the excellent care for the animals. Thanks to I. De Borle, P. Degryze, K. Desaedeleer, M. Mouton, A. Neesen and C. Snauwaert. Thanks to our IT-specialists N. Declerck and P. Vanhove. This project and K. De Swert were supported by the concerted research initiative of Ghent University (GOA project 98-6). 


\section{References}

1. Joos GF, De Swert KO, Pauwels RA. Airway inflammation and tachykinins: prospects for the development of tachykinin receptor antagonists. Eur J Pharmacol 2001; 429:239-50.

2. Wenzel SE, Fowler AA, III, Schwartz LB. Activation of pulmonary mast cells by bronchoalveolar allergen challenge. In vivo release of histamine and tryptase in atopic subjects with and without asthma. Am Rev Respir Dis 1988; 137:1002-8.

3. Nagai H, Yamaguchi S, Maeda Y, Tanaka H. Role of mast cells, eosinophils and IL-5 in the development of airway hyperresponsiveness in sensitized mice. Clin Exp Allergy 1996; 26:642-7.

4. Hessel EM, van Oosterhout AJ, Hofstra CL, de Bie JJ, Garssen J, Van Loveren H, Verheyen AK, Savelkoul HF, Nijkamp FP. Bronchoconstriction and airway hyperresponsiveness after ovalbumin inhalation in sensitized mice. Eur J Pharmacol 1995; 293:401-12.

5. Marshall JS, Waserman S. Mast cells and the nerves--potential interactions in the context of chronic disease. Clin Exp Allergy 1995; 25:102-10.

6. Suzuki R, Furuno T, McKay DM, Wolvers D, Teshima R, Nakanishi M, Bienenstock J. Direct neurite-mast cell communication in vitro occurs via the neuropeptide substance P. J Immunol 1999; 163:2410-5.

7. Cooke HJ, Fox P, Alferes L, Fox CC, Wolfe SA, Jr. Presence of NK1 receptors on a mucosal-like mast cell line, RBL-2H3 cells. Can J Physiol Pharmacol 1998; 76:18893.

8. Krumins SA, Broomfield CA. C-terminal substance P fragments elicit histamine release from a murine mast cell line. Neuropeptides 1993; 24:5-10.

9. Ansel JC, Brown JR, Payan DG, Brown MA. Substance P selectively activates TNFalpha gene expression in murine mast cells. J Immunol 1993; 150:4478-85.

10. Cross LJ, Heaney LG, Ennis M. Further characterisation of substance P induced histamine release from human bronchoalveolar lavage mast cells. Inflamm Res 1996; 45 Suppl 1:S11-S12.

11. Joos GF, Pauwels RA. The in vivo effect of tachykinins on airway mast cells of the rat. Am Rev Respir Dis 1993; 148:922-6. 
12. Janiszewski J, Bienenstock J, Blennerhassett MG. Picomolar doses of substance P trigger electrical responses in mast cells without degranulation. Am J Physiol 1994; 267:C138-C145.

13. Saria A, Hua X, Skofitsch G, Lundberg JM. Inhibition of compound 48/80--induced vascular protein leakage by pretreatment with capsaicin and a substance P antagonist. Naunyn Schmiedebergs Arch Pharmacol 1984; 328:9-15.

14. Hua XY, Yaksh TL. Pharmacology of the effects of bradykinin, serotonin, and histamine on the release of calcitonin gene-related peptide from C-fiber terminals in the rat trachea. J Neurosci 1993; 13:1947-53.

15. Levi-Montalcini R, Skaper SD, Dal Toso R, Petrelli L, Leon A. Nerve growth factor: from neurotrophin to neurokine. Trends Neurosci 1996; 19:514-20.

16. Levitt RC, Mitzner W. Autosomal recessive inheritance of airway hyperreactivity to 5hydroxytryptamine. J Appl Physiol 1989; 67:1125-32.

17. Szarek JL, Zhang JZ, Gruetter CA. Mechanisms of 5-hydroxytryptamine-induced contraction of isolated rat intrapulmonary bronchi. Pulm Pharmacol 1995; 8:273-81.

18. van Oosterhout AJ, Hofman G, Woutersen-Van Nijnanten FM, Nijkamp FP. 5-HT1like receptors mediate potentiation of cholinergic nerve-mediated contraction of isolated mouse trachea. Eur J Pharmacol 1991; 209:237-44.

19. Eum SY, Norel X, Lefort J, Labat C, Vargaftig BB, Brink C. Anaphylactic bronchoconstriction in BP2 mice: interactions between serotonin and acetylcholine. $\mathrm{Br}$ J Pharmacol 1999; 126:312-6.

20. Moffatt JD, Cocks TM, Page CP. Role of the epithelium and acetylcholine in mediating the contraction to 5-hydroxytryptamine in the mouse isolated trachea. Br J Pharmacol 2004; 141:1159-66.

21. Froger N, Gardier AM, Moratalla R, Alberti I, Lena I, Boni C, De Felipe C, Rupniak NM, Hunt SP, Jacquot C, Hamon M, Lanfumey L. 5-hydroxytryptamine (5-HT)1A autoreceptor adaptive changes in substance $\mathrm{P}$ (neurokinin 1) receptor knock-out mice mimic antidepressant-induced desensitization. J Neurosci 2001; 21:8188-97.

22. De Felipe C, Herrero JF, O'Brien JA, Palmer JA, Doyle CA, Smith AJ, Laird JM, Belmonte C, Cervero F, Hunt SP. Altered nociception, analgesia and aggression in mice lacking the receptor for substance P. Nature 1998; 392:394-7.

23. Tournoy KG, De Swert KO, Leclere PG, Lefebvre RA, Pauwels RA, Joos GF. Modulatory role of tachykinin NK1 receptor in cholinergic contraction of mouse trachea. Eur Respir J 2003; 21:3-10. 
24. Turner H, Kinet JP. Signalling through the high-affinity IgE receptor Fc epsilonRI. Nature 1999; 402:B24-B30.

25. De Swert KO, Tournoy KG, Joos GF, Pauwels RA. Role of the tachykinin $\mathrm{NK}_{1}$ receptor in airway changes in a mouse model of allergic asthma. J Allergy Clin Immunol 2004; 113:1093-9.

26. Casale TB, Wood D, Richerson HB, Zehr B, Zavala D, Hunninghake GW. Direct evidence of a role for mast cells in the pathogenesis of antigen-induced bronchoconstriction. J Clin Invest 1987; 80:1507-11.

27. Nagase T, Fukuchi Y, Dallaire MJ, Martin JG, Ludwig MS. In vitro airway and tissue response to antigen in sensitized rats. Role of serotonin and leukotriene D4. Am J Respir Crit Care Med 1995; 152:81-6.

28. Church MK. Response of rat lung to humoral mediators of anaphylaxis and its modification by drugs and sensitization. Br J Pharmacol 1975; 55:423-30.

29. Van de Voorde J, Joos G. Regionally different influence of contractile agonists on isolated rat airway segments. Respir Physiol 1998; 112:185-94.

30. Takahashi T, Ward JK, Tadjkarimi S, Yacoub MH, Barnes PJ, Belvisi MG. 5Hydroxytryptamine facilitates cholinergic bronchoconstriction in human and guinea pig airways. Am J Respir Crit Care Med 1995; 152:377-80.

31. Szarek JL, Zhang JZ, Gruetter CA. 5-HT2 receptors augment cholinergic nervemediated contraction of rat bronchi. Eur J Pharmacol 1993; 231:339-46.

32. Rizzo CA, Kreutner W, Chapman RW. 5-HT3 receptors augment neuronal, cholinergic contractions in guinea pig trachea. Eur J Pharmacol 1993; 234:109-12.

33. Buckner CK, Dea D, Liberati N, Krell RD. A pharmacologic examination of receptors mediating serotonin-induced bronchoconstriction in the anesthetized guinea pig. $\mathrm{J}$ Pharmacol Exp Ther 1991; 257:26-34.

34. Coleridge JC, Coleridge HM. Afferent vagal C fibre innervation of the lungs and airways and its functional significance. Rev Physiol Biochem Pharmacol 1984; 99:1110.

35. Chahl LA. Substance P mediates atropine-sensitive response of guinea-pig ileum to serotonin. Eur J Pharmacol 1983; 87:485-9.

36. Santarelli L, Gobbi G, Debs PC, Sibille EL, Blier P, Hen R, Heath MJS. Genetic and pharmacological disruption of neurokinin 1 receptor function decreases anxietyrelated behaviors and increases serotonergic function. Proc Nat Acad Sci Usa 2001; 98:1912-7. 


\section{Legends}

Figure 1

In vitro responses to increasing concentrations of 5-HT of tracheas from non-immunized, nonexposed tachykinin $\mathrm{NK}_{1}$ receptor knockout mice (closed circles, hatched line) versus wildtype mice (closed squares, closed line) $(n=8)$. Data are presented as mean \pm SEM. Tracheas from wild-type mice responded significantly more to 5-HT compared to tracheas from knockout mice.

Figure 2

In vitro responses to increasing concentrations of 5-HT of tracheas from non-immunized, nonexposed tachykinin $\mathrm{NK}_{1}$ receptor knockout mice (circles, hatched line) and wild-type mice (squares, closed line) in the presence (open symbols) and absence (closed symbols) of atropine $\left(10^{-6} M\right)(n=5)$. Data are presented as mean \pm SEM. Atropine decreased the responses of wild-type tracheas to 5-HT down to a level comparable with the responses from the knockout tracheas ( $<<0.05$ wild-type solvent vs. atropine). Responses of knockout tracheas to 5-HT were not influenced by atropine.

Figure 3

In vitro responses to 5-HT from tracheas of non-immunized, non-exposed tachykinin $\mathrm{NK}_{1}$ receptor knockout (circles, hatched line) and wild-type mice (squares, closed line) in the presence (open symbols) and absence (closed symbols) of TTX $\left(10^{-6} \mathrm{M}\right)(\mathrm{n}=5)$. Data are presented as mean \pm SEM. TTX-treated wild-type tracheas responded significantly less to 5HT compared to solvent treated counterparts $(\mathrm{p}<0.05)$. Responses from TTX-treated wildtype tracheas were not significantly different from responses of knockout tracheas. Responses of knockout tracheas to 5-HT were not influenced by TTX.

\section{Figure 4}

In vitro responses to 5-HT from tracheas from non-immunized, non-exposed tachykinin $\mathrm{NK}_{1}$ receptor WT mice in the presence (open squares) and absence (closed squares) of the tachykinin $\mathrm{NK}_{1}$ receptor antagonists RP67580 (10 $\left.{ }^{-7} \mathrm{M}, \mathrm{n}=6\right)(\mathrm{A})$ and SR140333 $\left(10^{-7} \mathrm{M}, \mathrm{n}=6\right)$ (B). Data are presented as mean \pm SEM. Responses were not influenced by these antagonists. 
Figure 5

Proposed mechanism to explain the difference in response to albumin and 5-HT between $\mathrm{NK}_{1} \mathrm{R}$ knockout and WT trachea: Addition of the allergen ovalbumin to sensitized mouse trachea in vitro causes the release of 5-HT from mast cells through activation of the high affinity IgE receptor FceRI. The released 5-HT mediates contraction through activation of receptors on smooth muscle and through activation of presynaptic receptors on cholinergic nerve endings, which induce the release of acetylcholine (ACh). This cholinergic mechanism is impaired in mice lacking the tachykinin $\mathrm{NK}_{1}$ receptor, probably through desensitisation / downregulation of the peripheral presynaptic 5-HT receptors on cholinergic nerve endings. 
TABLE 1: OVALBUMIN-INDUCED CONTRACTIONS OF MOUSE TRACHEA

\begin{tabular}{ccccc}
\hline \multirow{2}{*}{ Treatment } & \multicolumn{2}{c}{ WT (\% carb. max.) } & \multicolumn{2}{c}{ KO (\% carb. max.) } \\
\cline { 2 - 5 } & solvent & methysergide & solvent & methysergide \\
\hline PBS-exposed & $0.0 \pm 0.0$ & $0.0 \pm 0.0$ & $0.4 \pm 0.4$ & $0.0 \pm 0.0$ \\
OA-exposed & $11.6 \pm 2.9^{*}$ & $0.2 \pm 0.3^{\dagger}$ & $4.2 \pm 1.5^{*}$ & $0.6 \pm 0.4^{\dagger}$ \\
\hline
\end{tabular}

Definition of abbreviations: $\mathrm{WT}=$ tachykinin $\mathrm{NK}_{1}$ receptor wild type, $\mathrm{KO}=$ tachykinin $\mathrm{NK}_{1}$ receptor knockout, $\mathrm{PBS}=$ phosphate buffered saline, $\mathrm{OA}=$ ovalbumin $. \mathrm{n}=$ at least 4 .

Data as mean \pm SEM. ${ }^{*} \mathrm{p}<0.05$ vs PBS; ${ }^{\dagger} \mathrm{p}<0.05$ vs solvent, ${ }^{\ddagger} \mathrm{p}<0.05$ vs KO 
FIGURE 1

contraction

(\% carb max)

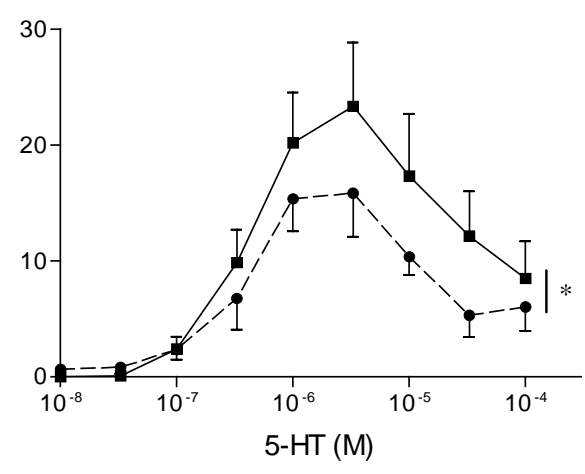


FIGURE 2

contraction

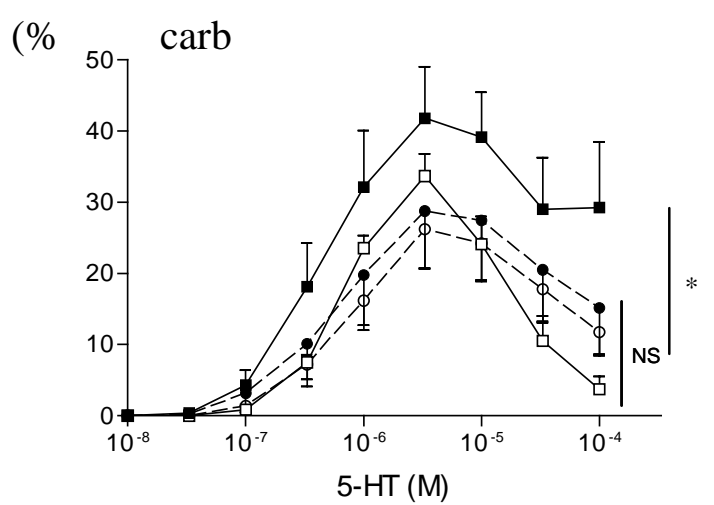




\section{FIGURE 3}

contraction

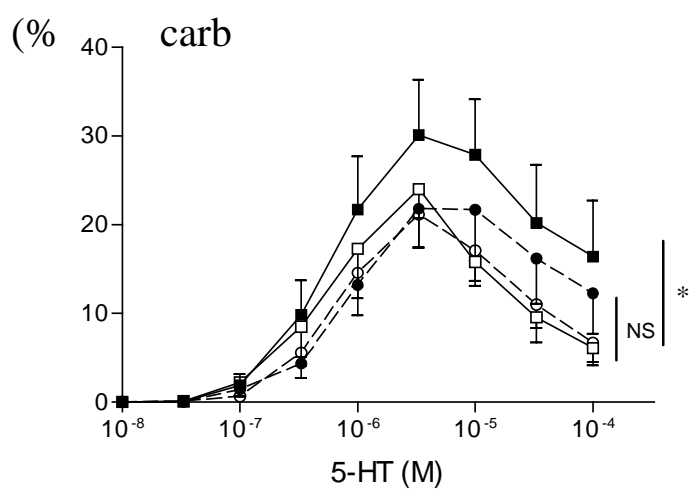


FIGURE 4

A

contraction

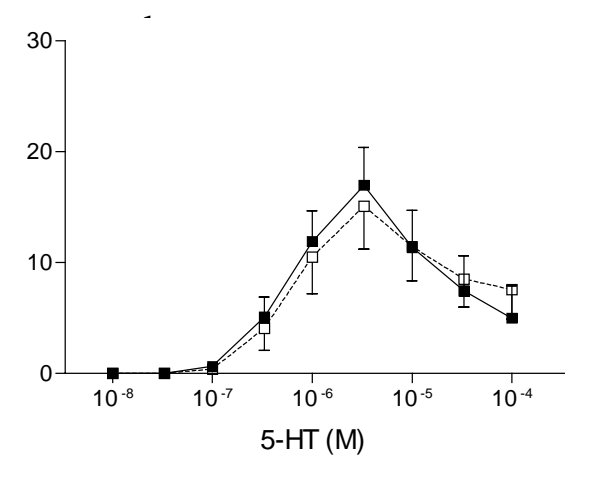

B

contraction

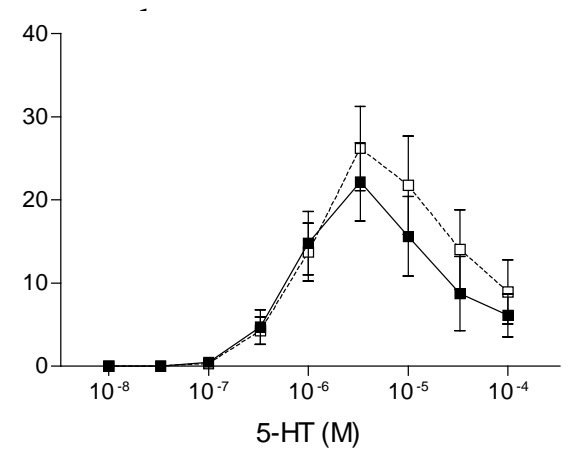




\section{FIGURE 5}

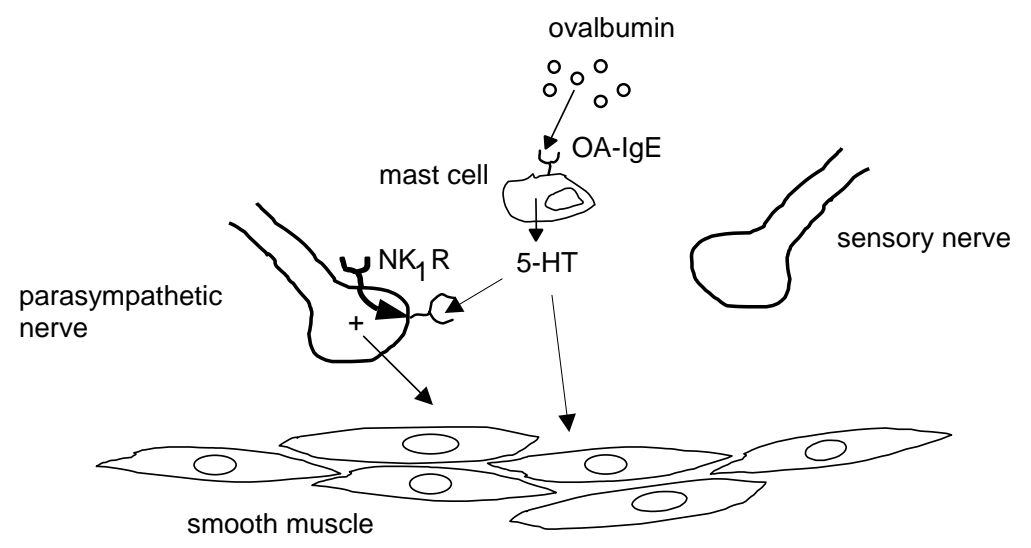

